\title{
PENGARUH PIJAT ENDORPHIN TERHADAP LAMA PENGELUARAN ASI
}

\section{THE EFFECT OF ENDORPHIN MASSAGE ON THE DURATION OF BREAST MILK REMOVAL}

\author{
Tri Budi Rahayu ${ }^{1 *}$, Evy Ernawati ${ }^{2}$ \\ *11 Stikes Guna Bangsa, Jalan Ring Road Utara Condongcatur Depok Sleman Yogyakarta, \\ email:triarahayu88@gmail.com, Indonesia \\ ${ }^{2}$ Stikes Guna Bangsa, Jalan Ring Road Utara Condongcatur Depok Sleman Yogyakarta, \\ email:evyernawati27@gmail.com, Indonesia
}

\begin{abstract}
Background:The production of breast milk which is less and slowly exits can cause the mother not to give enough milk to her baby. In addition to the hormone prolactin, the lactation process also depends on the hormone oxytocin, which is released from posterior pituitary as a reaction to nipple sucking. Oxytocin affects the myoepithelial cells that surround the alveoli so that the alveoli contracts and secretes milk that has been secreted by the mammary gland, this oxytocin reflex is affected by the mother's soul. If there is anxiety, stress and hesitation that occurs, then the expenditure of breast milk can be hampered. Various ways can be done to stimulate the oxytocin reflex. The endorphin massase method is used as an alternative way to provide comfort for labor pain and can increase the release of oxytocin substances.

Objective:This study aims to determine the effect of endorphin massage on breastfeeding in postpartum mothers.

Methods:This study was quasi experimental with a sample of postpartum mothers. The independent variable is endorphin massage, and the dependent variable is breastfeeding with a post test only design with control group design. The statistical test used was the Wilcoxon test.

Results:Based on the results of research conducted on 20 respondents, the results obtained from the non parametric statistical test 2 indepedence samples (Wilcoxon test) stated that the results of the Wilcoxon statistical test showed results $p=0.026<0.05$, meaning Ho was rejected and $\mathrm{H}$ I was accepted so that there was influence oxytocin massage against the time of milk removal.

Conclusion:There is an effect of oxytocin massage on the time of breastfeeding in postpartum mothers.
\end{abstract}

Keywords: Breastfeeding, endorphin massage, postpartum.

\section{PENDAHULUAN}

Penurunan angka kematian bayi (AKB) merupakan salah satu indikator meningkatnya derajat kesehatan dan kesejahteraan masyarakat. Berdasarkan penelitian badan kesehatan dunia (WHO) di enam negara berkembang termasuk di Indonesia, risiko kematian bayi antara 9-12 bulan meningkat $40 \%$ jika bayi tersebut tidak disusui. Angka kematian ini akan meningkat 48\% pada bayi berusia di bawah 2 bulan yang tidak disusui. Pemberian ASI eksklusif selama 6 bulan akan menurunkan kematian sebanyak 13\%, karena ASI mengandung zat antibodi yang dapat meningkatkan daya tahan tubuh bayi serta sangat bermanfaat bagi tumbuh kembang yang optimal, baik fisik, mental, maupun kecerdasan bayi. ${ }^{1}$

Beberapa regulasi telah ditetapkan oleh Pemerintah untuk meningkatkan cakupan pemberian ASI eksklusif di Indonesia. Regulasi yang diterbitkan pemerintah terkait dengan Program Peningkatan Pemberian ASI (PPASI) di antaranya Undang - Undang Nomor 36 tahun 2009 tentang Kesehatan dalam pasal 128 dan 129 dan Kepmenkes 
Nomor 450 Tahun 2004 tentang Pemberian Air Susu lbu secara Eksklusif pada Bayi di Indonesia. $^{2}$

Meskipun regulasi dan program telah ditetapkan oleh pemerintah, namun cakupan pemberian ASI eksklusifmasih jauh dari target nasional, yaitu sebesar $80 \%$. Berdasarkan hasil Riskesdas tahun 2010 menunjukkan bahwa cakupan pemberian ASI eksklusif bayi usia 0-5 bulan sebesar 27,2\%, sedangkan berdasarkan kelompok umur, bayi usia 5 bulan yang masih mendapat ASI eksklusif hanya sebesar $15,3 \%{ }^{2}$

Berbagai alasan dikemukakan oleh ibuibu yang tidak memberikan ASI eksklusif kepada bayinya, antara lain adalah ibu merasa produksi ASI kurang, kesulitan bayi dalam menghisap, ibu bekerja, keinginan untuk disebut modern, dan pengaruh iklan/promosi pengganti $\mathrm{ASI}^{3}$ Faktor lain yang memengaruhi keberhasilan menyusui adalah persiapan psikologis ibu sebelum menyusui. Stres, rasa kuatir yang berlebihan, ketidakbahagiaan pada ibu sangat berperan dalam menyukseskan pemberian ASI eksklusif. ${ }^{4}$

IImu pengetahuan saat ini telah mampu mengembangkan berbagai metode yang dimungkinkan dapat mengatasi permasalahan dalam pengeluaran ASI. Salah satu metode yang telah dikembangkan adalah pijat endorphin. Endorphin selama ini dikenal sebagai zat yang memiliki banyak manfaat, yaitu mengatur produksi hormon pertumbuhan dan seks, mampu mengurangi rasa nyeri/sakit, mengendalikan rasa stres, dan meningkatkan sistem kekebalan tubuh. Pijat endorphin merupakan teknik pemijatan ringan, yang membuat denyut jantung dan tekanandarah menjadi normal, serta membuat tubuh menjadi rileks. Pijat endorphin menciptakanrasa nyaman melalui permukaan kulit. Teknik ini juga terbukti mampu meningkatkan pelepasan oksitosin. ${ }^{5}$

Berbagai kegiatan yang dapat memicu munculnya endorphin dalam tubuh di antaranya relaksasi, meditasi, dan memberikan sugesti afirmasi positif pada ibu. Sugestif/afirmasi positif yang diberikan pada ibu mampu meningkatkan rasa percaya diri dan keyakinan yang kuat dalam pemberian ASI, terutama pada hari-hari pertama proses menyusui. Air susu ibu (ASI) akan keluar dengan lancar jika ibu merasa rileks, bahagia, dan percaya diri, sehingga bayi menjadi sehat dan ibu juga merasa semakin berarti sebagai seorang ibu yang menjadi tumpuan harapan si bayi. ${ }^{5}$

Berdasarkan latar belakang yang telah dikemukan, peneliti merumuskan permasalahan yaitu "Adakah pengaruh pijat endorphin terhadap lama pengeluaran ASI?". Tujuan dari penelitian ini adalah untuk mengetahui pengaruh pijat endorphin terhadap lama pengeluaran ASI, sehingga dapat membantu ibu nifas yang memiliki permasalahan dalam pengeluaran ASI, mengingat keberhasilan pemberian ASI eksklusif sangat ditentukan pada hari-hari pertama menyusui. 


\section{BAHAN DAN CARA PENELITIAN}

Penelitian ini merupakan eksperimental quasi (semu) dengan menggunakan rancangan post test only design with control group. Populasi dalam penelitian adalah ibu nifas di Praktik Mandiri Bidan (PMB) Kabupaten Bantul. Sampel diambil di salah satu PMB di Kabupaten Bantul dengan menghitung rata - rata ibu nifas dalam satu bulan. Dari perhitungan tersebut, didapatkan 10 ibu nifas yang dijadikan kelompok intervensi/perlakukan, dan 10 ibu nifas yang menjadi kelompok kontrol.

Data diambil langsung dari responden dengan menggunakan instrumen berupa check list. Pengambilan sampel menggunakan teknik consecutive sampling dimana ibu nifas yang datang secara berurutan dan memenuhi kriteria dimasukkan dalam penelitian sampai jumlah objek yang diperlukan terpenuhi. Adapun kriteria sampel sebagai berikut :

1. Ibu nifas dan memiliki masalah pengeluaran ASI,

2. Bayi yang tidak diberi susu formula,

3. Berat lahir bayi normal ( $\geq 2500$ gram).

Data yang didapatkan dianalisis dengan menggunakan uji statistik, yaitu uji Wilcoxon. Uji Wilcoxon digunakan untuk menganalisis hasil pengamatan yang berpasangan dari dua data apakah berbeda atau tidak. Uji Wilcoxon digunakan untuk data bertipe interval atau rasio, namun datanya tidak mengikuti distribusi normal.

\section{HASIL DAN PEMBAHASAN}

Tabel 1. Distribusi Frekuensi Karakteristik Responden Penelitian

\begin{tabular}{|c|c|c|c|c|c|c|}
\hline \multirow[t]{2}{*}{ No } & \multirow{2}{*}{\multicolumn{2}{|c|}{ Kategori Responden }} & \multicolumn{2}{|c|}{ Perlakuan } & \multicolumn{2}{|c|}{ Kontrol } \\
\hline & & & $\mathbf{f}$ & $\%$ & $\mathbf{f}$ & $\%$ \\
\hline \multirow[t]{4}{*}{1} & Status Gizi Saat Hamil & Lebih & 2 & 20 & 1 & 10 \\
\hline & & Cukup & 8 & 80 & 6 & 60 \\
\hline & & Kurang & 0 & 0 & 3 & 30 \\
\hline & Total & & 10 & 100 & 10 & 100 \\
\hline \multirow[t]{3}{*}{2} & Perawatan Payudara Selama Hamil & Melakukan & 7 & 70 & 3 & 30 \\
\hline & & Belum Melakukan & 3 & 30 & 7 & 70 \\
\hline & Total & & 10 & 100 & 10 & 100 \\
\hline \multirow[t]{4}{*}{3} & Dukungan Keluarga & Suami & 8 & 80 & 3 & 30 \\
\hline & & Orang tua & 2 & 20 & 6 & 60 \\
\hline & & Lainnya & 0 & 0 & 1 & 10 \\
\hline & Total & & 10 & 100 & 10 & 100 \\
\hline \multirow[t]{4}{*}{4} & Awal Waktu Pengeluaran ASI & $<24$ jam & 5 & 50 & 0 & 00 \\
\hline & & $24-48$ jam & 3 & 30 & 3 & 30 \\
\hline & & $>48$ jam & 2 & 20 & 7 & 70 \\
\hline & Total & & 10 & 100 & 10 & 100 \\
\hline
\end{tabular}

Berdasarkan tabel 1 dapat dilihat bahwa sebagian besar ibu nifas pada kelompok kontrol, lama pengeluaran ASI $>48$ jam
(70\%). Sedangkan ibu nifas pada kelompok perlakuan, sebagian besar lama pengeluaran ASI <24 jam (50\%). 
Pada tabel tersebut dapat dilihat bahwa sebagian besar ibu nifas pada kelompok kontrol belum melakukan perawatan payudara selama masa kehamilan (70\%), sedangkan ibu nifas pada kelompok perlakuan sebagian besar melakukan perawatan payudara selama hamil (70\%). Perawatan payudara sebaiknya dilakukan pada masa akhir kehamilan, terutama kehamilan bulan ketujuh (kehamilan trimester ketiga). ${ }^{6}$ Menurut Sherwood \& Lauralee (2011), pada kehamilan trimester ketiga laktogen plasenta mulai merangsang pembuatan ASI. Keaktifan dari rangsangan hormon-hormon terhadap pengeluaran air susu memengaruhi kecepatan dalam proses laktasi. $^{7}$

Kecepatan pengeluaran ASI pada ibu nifasmemberikan pengaruh terhadap kecepatan pemberian nutrisi awal untuk bayi baru lahir, karena ASI banyak mengandung protein dan antibodi yang sangat dibutuhkan bayi pada masa awal kehidupannya, mengingat sistem immunitas bayi masih sangat rentan terhadap suasana lingkungan di sekitarnya. Berdasarkan data tersebut dapat diasumsikan bahwa perawatan payudara yang dilakukan oleh ibu sejak masa kehamilan, terutama pada trimester ketiga dapat membantu mempercepat proses laktasi yang sudah mulai berproses di dalam tubuh ibu. Perawatan payudara selama kehamilan akan merangsang hormon-hormon yang memengaruhi pembentukan ASI, sehingga prosesnya akan lebih produktif dan awal pengeluaran ASI juga lebih cepat. Penelitian yang dilakukan oleh Maga,I, Buraerah, H. A,\& Andi,.Z. (2015) tentang faktor determinan produksi ASI pada ibu menyusui di Puskesmas Talaga Jaya Gorontalo menunjukkan bahwa penurunan produksi ASI pada ibu yang tidak melakukan perawatan payudara 3,433 kali lebih besar dibandingkan dengan yang melakukan perawatan payudara. $^{8}$

Pada tabel 1 juga dapat dilihat bahwa hanya 3 ibu nifas pada kelompok kontrol (30\%) yang mendapat dukungan suami saat proses awal menyusui. Sedangkan $80 \%$ ibu nifas pada kelompok perlakuan mendapat dukungan dari suami. Keberhasilan pemberian ASI eksklusif ditentukan oleh dukungan suami sebagai orang terdekat ibu. Suami yang mendukung pemberian ASI, 98\% ASI eksklusif berhasil, sedangkan suami yang tidak mendukung ASI keberhasilannya hanya $26 \%$ saja. $^{9}$ Menurut Sherwood \& Lauralee (2011) peran suami dalam proses menyusui sangat berpengaruh dalam meningkatkan hormon oksitosin, karena pengeluaran hormon oksitosin ini sangat dipengaruhi oleh pikiran ibu. ${ }^{7}$ Berdasarkan data tersebut dapat diasumsikan bahwa dukungan keluarga terutama suami dapat memengaruhi pengeluaran hormon oksitosin. Dukungan suami mampu menciptakan pikiran yang positif, perasaan nyaman dan tenang, sehingga akan menstimulasi hipofise posterior untuk mengeluarkan hormon oksitosin yang dapat merangsang sel alveoli 
untuk memproduksi ASI, sehingga waktu pengeluaran ASI lebih cepat.

Berdasarkan hasil penelitian, masih ada 1 ibu nifas pada kelompok kontrol yang memiliki status gizi lebih (10\%) dan 3 ibu nifas pada kelompok kontrol yang memiliki status gizi kurang (30\%). Sedangkan pada kelompok perlakuan, $80 \%$ ibu nifas memiliki status gizi cukup. Makanan yang dikonsumsi oleh ibu sangat berpengaruh terhadap produksi $\mathrm{ASI}^{10}$ Apabila ibu mengonsumsi makanan yang mengandung cukup gizi dan pola makan yang teratur, maka produksi ASI akan berjalan dengan lancar. Berdasarkan data tersebut dapat diasumsikan bahwa ibu yang memiliki status gizi kurang, produksi ASI dapat menurun, karena nutrisi dan vitamin yang dikonsumsi oleh ibu tidak terserap dengan baik di dalam tubuh, sehingga dapat memengaruhi proses laktasi.

Berdasarkan hasil analisa statistic non parametrik test 2 indepedence sample (uji Wilcoxon) diketahui bahwa nilai $p=0,026<0,05$, yang bermakna bahwa Ho ditolak dan $\mathrm{H}$ s diterima sehingga terdapat pengaruh pijat oksitosin terhadap awal pengeluaran ASI. Sebagian besar ibu nifasyang diberikan perlakuan pijat endorphin didapatkan hasil bahwa awal pengeluaran ASI <24 jam sebanyak 5 orang (50\%). Pijatan atau rangsangan pada tulang belakang, akan melepaskan neurotransmitter yang akan merangsang medulla oblongata dan langsung mengirim pesan ke hypothalamus di hipofise posterior untuk mengeluarkan oksitosin yang menyebabkan payudara mengeluarkan air susunya. ${ }^{11}$ Selain itu, pijatan pada daerah tulang belakang ini juga akan mengurangi ketegangan dan stres, sehingga hormon oksitosin keluar dan akan membantu pengeluaran ASI, yang dibantu dengan isapan bayi pada puting susu segera setelah bayi lahir.

Berdasarkan data tersebut dapat diasumsikan bahwa adanya pengaruh pijat endorphin terhadap awal pengeluaran ASI dipengaruhi oleh perawatan payudara selama hamil dan dukungan keluarga terutama suami, yang bekerja dengan cara menstimulasi hipofise posterior untuk meningkatkan pengeluaran hormon oksitosin di mana hormon tersebut dihasilkan dari rasa nyaman, tenang, tidak mengalami stres. Peningkatan hormon oksitosin meningkat akan menstimulasi hipofise anterior untuk mengeluarkan hormon prolaktin yang dapat merangsang sel alveoli, sehingga produksi ASI dapat meningkat.

\section{KESIMPULAN}

1. Berdasarkan hasil penelitian dapat disimpulkan bahwa sebagian besar ibu nifas yang tidak dilakukan pijat endorphin mempunyai awal pengeluaran $\mathrm{ASI}>48$ jam.

2. Sebagian besar ibu nifas yang telah dilakukan pijat endorphin mempunyai awal pengeluaran $\mathrm{ASI}<24$ jam.

3. Ada pengaruh pijat endorphine terhadap lama pengeluaran ASI. 


\begin{abstract}
Saran utamanya diberikan kepadapeneliti bahwa perlu dilakukan penelitian lebih lanjut terkait jangka waktu pemijatan endorphin terhadap lama pengeluaran ASI pada ibu nifas dan letak pijatan yang tepat.
\end{abstract}

\section{TERIMA KASIH}

1. Dr. dr. Soerjo Hadijono, Sp. OG, (K), DTRM \& B $(\mathrm{CH})$ selaku Ketua STIKES Guna Bangsa Yogyakarta dengan alamat email srobgyn@hotmail.com

2. Dian Wuri Astuti, S.Si., M.Sc Selaku Ketua LPPM STIKES Guna Bangsa Yogyakarta dengan alamat email dianawa.gunabangsa@gmail.com

3. Siti Fadhilah, S.SiT., M.Kes selaku Ketua Program Studi D3 Kebidanan STIKES Guna Bangsa Yogyakarta dengan alamat email dhilafadh@gmail.com

\section{KEPUSTAKAAN}

1. Roesli, U..Inisiasi Menyusu Dini Plus ASI Eksklusif. Jakarta: Pustaka Bunda; 2008

2. Kemenkes RI. Riset Kesehatan Dasar. Badan Peneliti dan Pengembangan Kesehatan kemenkes RI. Jakarta: 2010.

3. Siregar, A. Pemberian ASI Eksklusif dan Faktor-Faktor yang Mempengaruhinya. Medan : FKM USU; 2004.

4. UNICEF. Breast Crawl:Initiation of Breastfeeding by Breast Crawl. Breast Crawl.org: 2007.

5. Widayanti, Wiwin. Efektivitas metode 'SPEOS' (Stimulasi Pijat Endorphin, Oksitosin, dan Sugestif) terhadap Pengeluaran ASI pada lbu Nifas di Wilayah Kabupaten Cirebon.Tesis. Semarang. Program Studi Magister Epidemiologi. UNDIP; 2014.

6. Astutik, R.Y. Payudara dan laktasi. Jakarta: Salemba Medika; 2014.
7. Sherwood\& Lauralee. Fisiologi Manusia Dari Sel ke Sistem (Human Physiology: From Cells to System). Jakarta: EGC; 2011.

8. Maga,I., Buraerah, H.A.,Andi,.Z.. Determinant Factors Breastmilk Production In Publik Health Centre Talaga Jaya Gorontalo Regency Gorontalo Province. Artikel IImiah. Gorontalo: Politeknik Kesehatan Gorontalo; 2015

9. Desmawati. Penentu Kecepatan Pengeluaran Air Susu Ibu Setelah Sectio Caesar. 2013. http://Jurnalkesmas.ui.id/index.php/kesma s/article/view/22.. Diunduh tanggal 19 Februari 2018.

10. Sukarni, W. Buku Ajar Keperawatan Maternitas. Yogyakarta: Nuha Medika; 2013.

11. Roesli, U., Yohwi, EBedah ASI: Manajemen Laktasi. Jakarta: Balai penerbit FKUI; 2009 